\title{
PROMOTION OF POLYLACTID ACID ECO-FRIENDLY BY COMBINED ADDITION OF PCL CATECHIN-CHITOSAN UNDER EXTRUDING CONDITION
}

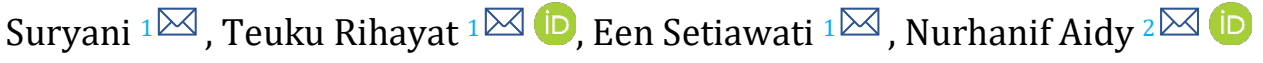 \\ ${ }^{1}$ Department of Chemical Engineering, Politeknik Negeri Lhokseumawe, Lhokseumawe, Aceh 24301, \\ Indonesia. \\ ${ }^{2}$ Department of Renewable Energy Engineering, Universitas Malikussaleh, Blang Pulo, Muara Satu, North Aceh, \\ Aceh 24355, Indonesia.
}

Received 12 October 2021

Accepted 1 November 2021

Published 30 November 2021

Corresponding Author

Suryani, suryani.salimpnl@gmail.com

DOI

10.29121/granthaalayah.v9.i11.2021 4380

Funding: This research received no specific grant from any funding agency in the public, commercial, or not-for-profit sectors.

Copyright: (C) 2021 The Author(s). This is an open access article distributed under the terms of the Creative Commons Attribution License, which permits unrestricted use, distribution, and reproduction in any medium, provided the original author and source are credited.

\section{ABSTRACT}

Biodegradable polymers are seen as a potential solution for the environment generated by plastic waste. The purpose of this study was to see the effect of adding a catalyst to the manufacture of PLA/PCL-Catechin-Chitosan as a raw material for making plastics. This research was carried out with variations in the addition of $\mathrm{ZnO}$ catalyst $0.1 \%$ (PPXya), $0.2 \%$ (PPXyb) and $0.3 \%$ (PPXyc). From the results of the analysis using Fourier Transform Infrared (FTIR) obtained stretching groups of $\mathrm{OH}, \mathrm{CO}$ and $\mathrm{C}=\mathrm{O}$ at wavelengths (3860, 1060 and 1753) $\mathrm{cm}^{-1}$ at the addition of $0.3 \% \mathrm{ZnO}$ catalyst (PPXyc). Based on the analysis of the thermal stability using Thermogravimetry (TGA) the decomposition temperature was obtained at $387^{\circ} \mathrm{C}$ with the addition of catalyst $0.3 \%$ (PPXyc). Morphological analysis using Scanning Electron Microscopy (SEM) showed that the surface structure of PLA was in the form of widespread lumps. The more concentration of additional catalyst used can affect the formation of PLA/PCL-Catechin-Chitosan. The result of the tensile test tensile analysus are greater the addition of $\mathrm{ZnO}$ catalyst in the sample PLA-PCL-Catechin-hitosan can to be able to increase the tensile value of the of the sample.

Keywords: Polylactic Acid, Poly Caprolactone, Catechin, Chitosan, Zno Catalyst

\section{INTRODUCTION}

The depletion of fossil resources and the remaining undegraded plastics cause environmental pollution and harmful carbon dioxide is trapped in the atmosphere. Nelly et al. (2020)Currently, many packaging products are made of plastic, there are about 50\% plastic packaging products, most of which are produced from fossil fuels. as the development of biodegradable materials that can be degraded in an environmentanlike conventional plastics which can help reduce emissions of greenhouse glly friendly manner in a relatively short time. Bio-based polymers can play an important role, uases such as carbon dioxide. In addition, the production and use of biodegradable polymers can also help increase the rate at which fossil fuels increase. Fitria et al. (2020), Prapruddivongs et al. (2014), Sun and Pei (2017).

For the current era, research on environmentally friendly products will be of great concern to many researchers and industry players, especially in the polymer field. Several polymer materials derived from environmentally friendly materials (biopolymers) have been produced, such as Poly HydroxyAlkanoate 
(PHA), Poly Hydroxy Butyrate (PHB), and Poly Lactid Acid (PLA). Rihayat and Suryani (2010), Arfat et al. (2018)

One of the biopolymers that is currently being researched is PLA (Poly Lactid Acid) due to its biodegradability so that it is classified as an environmentally friendly polymer. Unlike synthetic polymers in general which are derived from petroleum materials, PLA comes from renewable sources, namely from various kinds of plants that have a highstarch content such as cassava, sweet potato, banana, corn and so on. The formation of PLA can be through esterification of lactic acid obtained by fermentation by bacteria using starch or simple sugars as a substrate. Indumathi and Rajarajeswari (2019), Chen et al. (2018), Najafi et al. (2012)

Some properties Poly lactic acid (PLA) which has some attractive properties such as biocompatibility, high strength, stiffness, and thermoplastic, but has low impact strength. Therefore, it is necessary to add another polymer material, namely PCL (C6H1002) which is known as a commercial biodegradable polymer with a rather low melting point of around $600^{\circ} \mathrm{C} .10$ It is a type of biodegradable, hydrophobic and partially crystalline polyester with good mechanical properties suitable for packaging applications. However, due to the high price of PCL compared to other types of polymers. Najafi et al. (2012), Jamshidian et al. (2010)

The use of PCL is still limited for packaging applications. To reduce production costs and increase utility, PCL is often reinforced or mixed with other materials or low-cost polymers such as bentonite and chitosan. This will not only overcome the limitations of industrial polymers, but also improve the mechanical and physical properties of the composite. The most common use of polycaprolactone is in the manufacture of specialty polyurethanes. Lopes (2014), Mansa et al. (2015), Raquez et al. (2013), Yoyon (2012) These polymers are often used as additives to resins thereby improving their processing characteristics and final use properties of resins for example, impact resistance compatible with various other materials, PCL can be mixed with flour to lower costs and increase biodegradation or can be added as a plasticizer polymer for PVC. Suryani et al. (2017), Rihayat et al. (2018), Zulkifli et al. (2018)

Furthermore, in accordance with the improvement of packaging material quality standards, the addition of materials to prevent migration on the surface of the material is something that cannot be avoided. Chitosan is a polysaccharide obtained by deacetylation of chitin and has many applications due to its excellent oxygen blocking properties, antimicrobial properties, biodegradability, biocompatibility and non-toxicity. One of the important properties of chitosan is the ability to interact with cells and cellular lysozyme which is able to degrade microbes in vivo. Arfat et al. (2018)

\section{MATERIALS AND METHODS}

\subsection{MATERIALS}

The materials used in this study were solid lactic acid supplied from Merck, Germany where the melting point was $150-160^{\circ} \mathrm{C}$, Poly(hexano-6-lactone) pallets with a density of $1.14 \mathrm{~g} / \mathrm{cm} 3$ where the melting point was 600C supplied from Merck Germany, catechins were supplied from Merck, chitosan was obtained from Sigma

Aldrich, solid ZnO catalyst from Merck, 96\% ethanol as a solvent in the synthesis of PLA and PCL, technical methanol was supplied from Merck, and chloroform as a solvent in the synthesis of PCL. 


\subsection{METHODS}

\subsubsection{SYNTHESIS OF OLIGOMER}

The oligomer synthesis process from commercial lactic acid was carried out using a $500 \mathrm{~mL}$ Erlenmeyer equipped with a vacuum pump with a pressure of 300 $\mathrm{mmHg}$ at $100^{\circ} \mathrm{C}$, stirring was carried out at a speed of $150 \mathrm{rpm}$ using a magnetic stirrer for 2 hours. Jaafar et al. (2019), Moataz et al. (2017), Kian et al. (2019)

\subsubsection{SYNTHESIS OF LACTIDA}

The oligomers formed were added with $0.1 \% \mathrm{ZnO}$ catalyst (PPXya); $0.2 \%$ (PPXyb) and $0.3 \%$ (PPXyc) were heated at $120^{\circ} \mathrm{C}$ and stirred until homogeneous and connected by vacuum suction at a pressure of $300 \mathrm{mmHg}$. Zejun et al. (2018)

\subsubsection{SYNTHESIS OF LACTIDA}

The lactide produced weighs 1 gram. Then put into $500 \mathrm{~mL}$ Erlenmeyer by adding $0.15 \% \mathrm{ZnO}$ catalyst, $5 \mathrm{~mL}$ ethanol and heated by condensation at $120^{\circ} \mathrm{C}$ with polymerization time for 3 hours. The resulting PLA was dissolved using chloroform $(1: 1 \mathrm{w} / \mathrm{v})$ and precipitated in methanol $(1: 3 \mathrm{v} / \mathrm{v})$ for purification. Finally, pure PLA was dried in an oven at $800^{\circ} \mathrm{C}$ for $1-2$ hours. Zibiao et al. (2016), Yildirim et al. (2018), Shady et al. (2016), Ling-Yu Li et al. (2018), Palacioet al. (2018)

\subsubsection{MIXING PLA-PCL CATECHIN AND CHITOSAN}

PLA and PCL will be dried in a vacuum oven at a temperature of $\pm 40^{\circ} \mathrm{C}$ for 24 hours. Then, after drying, the composite samples were molded using an extruder operated at a temperature of $180^{\circ} \mathrm{C}$ using a special blending process for 12 sample formulations with different concentrations in each sample. In each polymer PCL and PLA were mixed $40: 60$ with catechin+chitosan in a ratio of $2 \%, 4 \%, 6 \%$ and $8 \%$. Then PCL and PLA were mixed in a ratio of 50:50 where the total mass of PLA+PCL was $10 \mathrm{~g}$, then filled with catechin+chitosan in a ratio of $2 \%, 4 \%, 6 \%$ and $8 \%$. The last sample was mixed with PCL and PLA in a ratio of 60:40 with a total mass of PLA+PCL $10 \mathrm{~g}$, then filled with a mixture of catechins+chitosan in a ratio of $2 \%, 4 \%$, $6 \%$ and $8 \%$.

\subsubsection{EFFECT OF ZNO CATALYST ON POLY LACTID ACID (PLA)}

$\mathrm{ZnO}$ is an inorganic compound. $\mathrm{ZnO}$ has a hardness that is not too high and is only at level 4.5 on the moss scale. $\mathrm{ZnO}$ has a high thermal conductivity and capacity, as well as a high melting temperature $\left(1.975^{\circ} \mathrm{C}\right)$. The molar mass of $\mathrm{ZnO}$ is 81.38 $\mathrm{g} / \mathrm{mol}$ with a density of $5.606 \mathrm{~g} / \mathrm{cm} 3$. As well as having piezoelectric properties, it can change color from white to yellow when heated and returns to white when cooling. Daria et al. (2020)

Commercial lactic acid was added to the Erlenmeyer as much as $50 \mathrm{~mL}$ with a stirring speed of $150 \mathrm{rpm}$ and the polycondensation process for 2 hours. After the polycondensation process, $\mathrm{ZnO}$ catalyst was added with variations of $0.1 \%, 0.2 \%$ and $0.3 \%$ for 2 hours. The lactide produced from the polycondensation process was added with $0.15 \% \mathrm{ZnO}$ catalyst and $5 \mathrm{~mL}$ of ethanol was added at a stirring speed of $150 \mathrm{rpm}$. Furthermore, the final stage is polymerization where this process is to produce poly lactic acid (PLA), this process is carried out with variations of the process of 2 and 3 hours at a stirring speed of $150 \mathrm{rpm}$. Poly lactic acid (PLA) was 
then dissolved using chloroform and precipitated with methanol. Finally, poly lactic acid (PLA) is separated between solids and liquids using filtration with the help of a vacuum pump to speed up the filtration process. The following is a sample of poly lactic acid (PLA) obtained with the addition of $0.3 \% \mathrm{ZnO}$ catalyst in the polymerization process for 2 hours.

Marraa's research in 2016 stated that poly lactic acid (PLA) with the addition of 1.3 and $5 \% \mathrm{ZnO}$ (zincoxide) provided an improvement in the photodegradation resistance of PP to ultraviolet irradiation and produced good mechanical and thermal properties. This was followed by Hu's 2017 study which stated that under optimal reaction conditions, lactide was produced at a yield of $91-92 \%$ at 8 hours and significantly increased the synthesis efficiency compared to the conversion tinbased catalytic method. Pure lactide products convert food-derived lactic acid into poly (lactic acid) molecules $\left(150,000 \mathrm{~g} \mathrm{~mol}^{-1}\right)$ which are then used to make fibers with promised tensile and thermal properties for textile and bioplastic applications.

\subsubsection{FOURIER TRANSFORM INFRARED (FTIR)}

FTIR is a very common tool used to identify chemical solutions of organic and inorganic materials. This tool can also be applied to analyze solids, solutions as well as gases. FTIR produces data that can be analyzed in the form of an interface as well as in the form of a spectrum. An FTIR spectrometer (Nicolet iS50ATR-Thermo Fisher Scientific) was used to record the FTIR spectra of clean PU and CPN films, in the scan range from $4000 \mathrm{~cm}^{-1}$ to $400 \mathrm{~cm}^{-1}$ and with a resolution of $4 \mathrm{~cm}^{-1}$. For each specimen, an average of 32 scans recorded.

\subsubsection{ANALYSIS OF THERMOGRAVIMETRIC (TGA)}

TGA analysis was carried out using the Shimadzu DTG-60 instrument, which studied the mass change of the sample as a function of temperature, time and atmosphere. In principle this method measures the reduced mass of a material when heated from room temperature to a high temperature which is usually about $800^{\circ} \mathrm{C}$ at a heating rate of $20 \mathrm{C} / \mathrm{min}$. The analysis is carried out by gradually increasing the temperature of the sample and determining the large loss of temperature change. All specimens were tested under nitrogen gas stream.

\subsubsection{SCANNING ELECTRON MICROSCOPE (SEM)}

SEM is used to determine the morphology or surface structure of the material. In principle, if there is a change in the surface, then the material has undergone a change in energy. Energy can be emitted, reflected and absorbed and converted into an electromagnetic wave function so that it can be read on SEM photos.

\section{RESULTS AND DISCUSSIONS}

In this study, the best results from the tests that have been carried out will be presented. The following is a table of observations using Fourier Transform Infrared (FTIR), Thermogravimetry (TGA) and Scanning Electron Microscopy (SEM).

\subsection{FOURIER TRANSFORM INFRA-RED SPECTROPHOTOMETER (FTIR)}

Fourier Transform Infra-Red Spectrophotometer (FTIR), is a method of characterizing chemical properties using infrared spectoscopy. Infrared radiation is 
passed to the sample which is then part of the radiation is absorbed by the sample and part of it is transmitted so that the output will come out in the form of a transmission that forms a fingerprint of the resulting infrared spectrum. If a beam of infrared light is passed through a polymer sample, the molecule will adopt some of its frequencies, some of which will be transmitted. Aneta et al. (2020) The obtained PLA products were then analyzed using a Shimadzu FTIR spectrophotometer with the addition of $\mathrm{KBr}$ pellets. This characterization was carried out with the aim of knowing the functional group of poly lactic acid (PLA). The following is a graph of the Fourier Transform Infrared (FTIR) test.

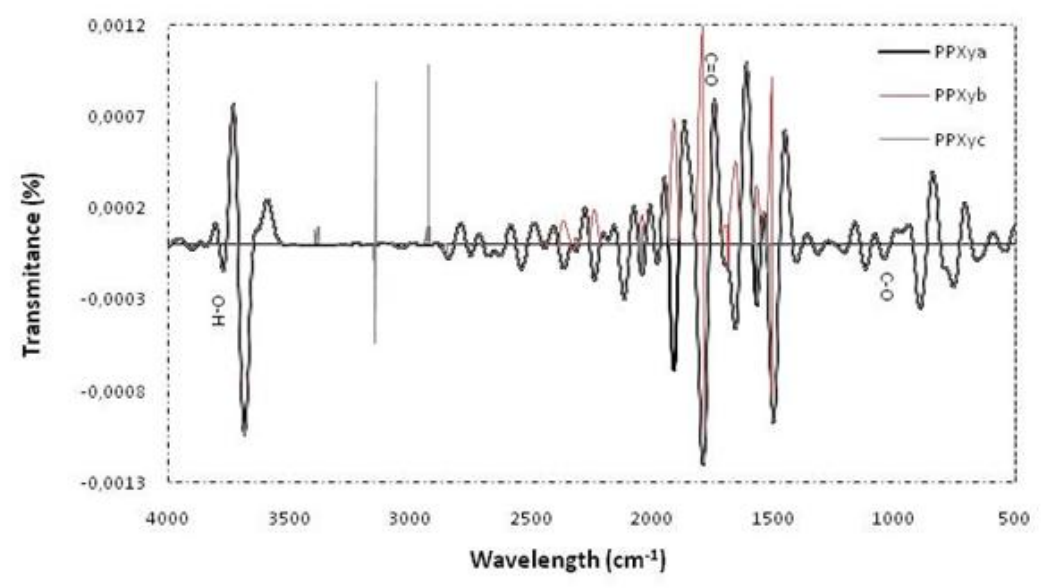

Figure 1 FTIR Spectrum of PLA / ZnO Samples

Figure 1 shows the PLA/PCL-Catechin-Chitosan with the addition of $0.1 \%$ catalyst (PPXya) the formation of $\mathrm{O}-\mathrm{H}, \mathrm{C}-\mathrm{O}$ and $\mathrm{C}=\mathrm{O}$ groups. In the $\mathrm{O}-\mathrm{H}$ group the wavelength obtained is $2767 \mathrm{~cm}^{-1}$. For C-O the obtained wavelength is $1012 \mathrm{~cm}^{-1}$. And for the $\mathrm{C}=0$ group, the wavelength value obtained is $1138 \mathrm{~cm}^{-1}$, the results obtained are better than without the addition of $\mathrm{ZnO}$ catalyst. $\mathrm{ZnO}$ has a hardness that is not too high and is only at level 4.5 on the moss scale. ZnO has a high thermal conductivity and capacity, as well as a high melting temperature $\left(1,975^{\circ} \mathrm{C}\right)$. The molar mass of $\mathrm{ZnO}$ is $81.38 \mathrm{~g} / \mathrm{mol}$ with adensity of $5.606 \mathrm{~g} / \mathrm{cm} 3$. As well as having piezoelectric properties, it can change color from white to yellow when heated and returns to white when cooling. Wang et al. (2019)

Then, for the addition of $0.2 \% \mathrm{ZnO}$ catalyst (PPXyb), $\mathrm{O}-\mathrm{H}$ clusters were formed with a wavelength of $2902 \mathrm{~cm}^{-1}$. The C-O group of wavelength values obtained is $1022 \mathrm{~cm}^{-1}$. And in the $\mathrm{C}=0$ group the wavelength obtained is $1202 \mathrm{~cm}^{-1}$. While the addition of $0.3 \% \mathrm{ZnO}$ catalyst (PPXyc) the formation of $\mathrm{O}-\mathrm{H}$ groups obtained at a wavelength of $3862 \mathrm{~cm}^{-1}$ during the polymerization process for 2 hours. The C-O functional group in the 2-hour polymerization process obtained a wavelength of $1063 \mathrm{~cm}^{-1}$. And for the $\mathrm{C}=0$ group, the wavelength obtained is $1757 \mathrm{~cm}^{-1}$. In Rasmita's research in 2012 stated that the results of the analysis using FTIR obtained $\mathrm{OH}$ groups at a wavelength of $3418.44 \mathrm{~cm}^{-1}$, and at a wavelength of 1272.11 $\mathrm{cm}^{-1}$ obtained CO groups, while for a wavelength of $3505.28 \mathrm{~cm}^{-1}$ there was no $\mathrm{C}=0$ group.

\subsection{THERMOGRAVIMETRIC (TGA)}

Analytical or thermal gravimetric thermogravimetry (TGA) is a type of test performed on samples to determine the change in weight-loss in relation to changes 
in temperature. Simultaneous measurement of two material properties not only increases productivity, but also simplifies interpretation of results.

The principle of using TGA is to measure the average speed of change in the mass of a material/ sample as a function of temperature or time in a controlled atmosphere. Measurements are used in particular to determine the composition of a material or sample and to estimate its thermal stability at temperatures above $1000^{\circ} \mathrm{C}$. This method can characterize a material or sample as seen from the loss of mass or the occurrence of decomposition, oxidation or dehydration.

Thermogravimetric analysis (TGA) was performed to assess the thermal stability of PLA using a Shimadzu DTG-60 simultaneous DTA-TG instrument. Prior to analysis, the sample was weighed with a mass of $0.6 \mathrm{mg}$ and heated at room temperature to $600^{\circ} \mathrm{C}$ with a heating rate of $200 \mathrm{C} /$ minute. The container used is aluminum so that the heating temperature reaches $600^{\circ} \mathrm{C}$ and if the container used is platinum, the combustion temperature will reach $1,200^{\circ} \mathrm{C}$.

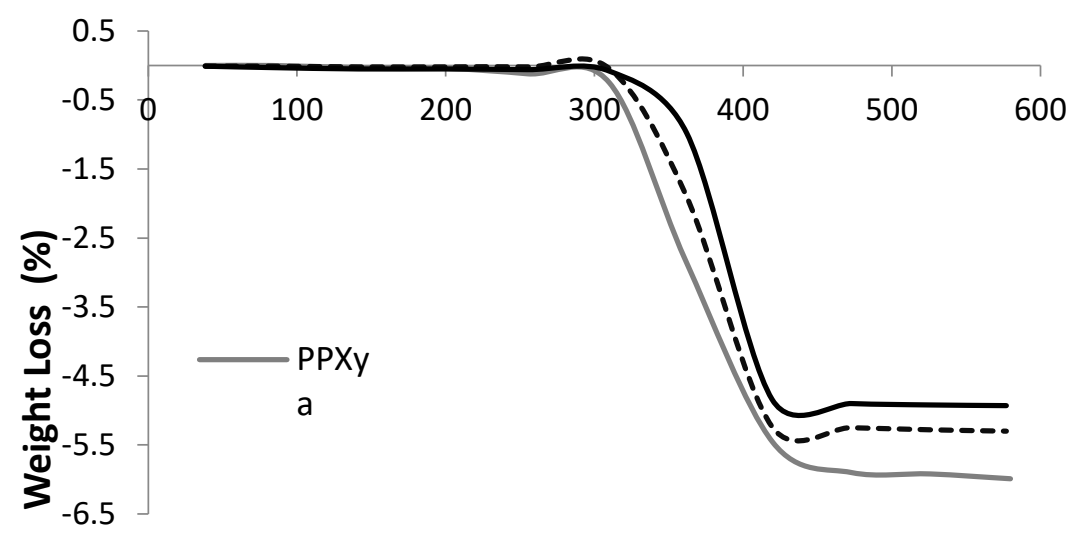

Temperature $\left({ }^{\circ} \mathrm{C}\right)$

Figure 2 Graph of TGA Analysis Result

Figure 2 shows that PLA/PCL-Catechin-Chitosan with the addition of a $0.1 \%$ ZnO catalyst (PPXya) during the polymerization process of 2 hours, the decomposition temperature of the PLA sample is $361^{\circ} \mathrm{C}$. For PLA/PCL-CatechinChitosan with the addition of $0.2 \% \mathrm{ZnO}$ catalyst (PPXyb) with a polymerization process time of 2 hours, the decomposition temperature of the PLA sample was found at $375^{\circ} \mathrm{C}$. And PLA/PCL-Catechin-Chitosan with the addition of $0.3 \% \mathrm{ZnO}$ catalyst (PPXyc) during the polymerization process of 2 hours, the decomposition temperature of the PLA sample was at $387^{\circ} \mathrm{C}$, the decomposition occurred due to the process of breaking chemical bonds. In Zhang's research in 2016 stated that $\mathrm{ZnO} / \mathrm{PLA}$ obtained the value of thermal stability at a temperature of $385^{\circ} \mathrm{C}$ for 2 hours.

\subsection{SCANNING ELECTRON MICROSCOPE (SEM)}

Scanning Electron Microscope is a type of electron microscope that depicts the surface of a sample through a scanning process using a high-energy beam of electrons in a raster scan pattern. Electrons interact with atoms that will make the sample generate signals and provide information about the sample's surface topography, composition and other properties such as electrical conductivity.

In principle, if a material changes its surface, then the material has undergone a change in energy. The energy is emitted and absorbed so that it is converted into a function of electromagnetic waves and can be read through SEM photos. Ling-Yu 
Li et al. (2018), Palacio et al. (2018) The following is an image of the analysis using Scanning Electron Microscopy (SEM). Test results using Scanning Electron Microscopy (SEM) at a treatment distance of 200x magnification on PLA/PCLCatechin-Chitosan with the addition of a $\mathrm{ZnO}$ catalyst of $0.1 \%$ (PPXya), $0.2 \%$ (PPXyb) and $0.3 \%$ (PPXyc) at the time of the polymerization process for 2 hours showed that the surface structure of poly lactic acid (PLA) was widely spread due to electromagnetic rays.

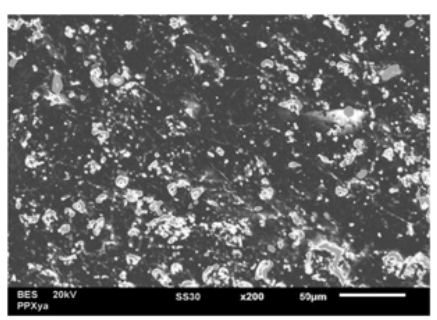

(PPXya) $0,1 \%$

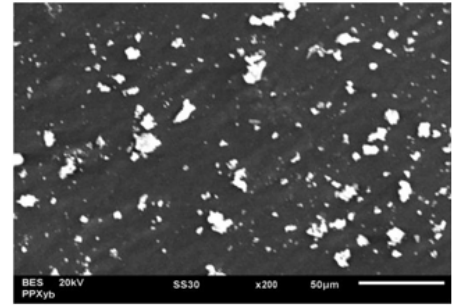

(PPXyb) 0,2\%

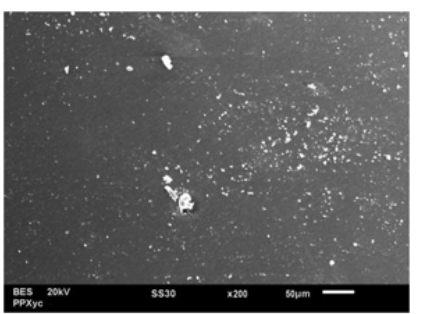

(PPXyc) $0,3 \%$

Figure 3 (a) (b) (c) PLA/PCL-Catechin-Chitosan /ZnO Analysis SEM

Based on Figure 3 is the result of testing using Scanning Electron Microscopy (SEM) at 200x magnification distance treatment on PLA/PCL-Catechin-Chitosan with the addition of a $\mathrm{ZnO}$ catalyst of $0.1 \%$ (PPXya), $0.2 \%$ (PPXyb) and 0, 3\% (PPXyc) during the polymerization process for 2 hours, it can be seen that PLA/PCLCatechin-Chitosan with the addition of $0.1 \% \mathrm{ZnO}$ catalyst (PPXya) can be seen in the picture above there are many sample lumps that are widely spread due to electromagnetic radiation.. With the addition of $0.2 \%$ catalyst (PPXyb) for PLA/PCLCatechin-Chitosan, the characteristic obtained is that the sample lumps obtained are less than 0.1\% PPXya. Furthermore, PLA/PCL-Catechin-Chitosan with the addition of $0.3 \% \mathrm{ZnO}$ catalyst (PPXyc) the sample lumps became smoother and not visible in this characteristic. In a 2016 Marraa study, it was stated that PLA/ZnO 1\%, 2\% and $3 \%$ by weight had more effective anti-bacterial properties after propagation of E.Coli bacteria for 7 days, for biocomposites with the addition of $\mathrm{ZnO}$ as much as $3 \%$ by weight showed anti-bacterial properties against S.Aureus on the seventh day. This was followed by 33 which stated that the surface layer of the sample showed good smoothness and the absence of pores, this was due to the increased NP aggregate in the layer, thus the stronger antimicrobial activity of the material. Wang et al. (2019)

\subsection{TENSILE STRENGTH}

The combination of PLA/PCL/Catechin/Chitosan which has been molded according to the ASTM D 38 specimen standard is tested for its mechanical properties with an indicator of the level of tensile strength through the axial force provided by the tensile test equipment until it reaches the maximum limit until it breaks. Based on the tests carried out, it was seen that there was an effect of the addition of catechins and chitosan on PCL/PLA. J.bonilla et al in their research added chitosan to PLA and showed a decrease in tensile strength. However, the results obtained are inversely related to the observed results 33 . The addition of $0.2 \%$ catechin and chitosan filler in PPXyb resulted in an increase in the tensile strength value of $50.46 \mathrm{MPa}$, in this section the difference in results was obtained as shown in Table 1. 


\begin{tabular}{|cc|}
\hline Table 1 Tensile test result obtained \\
\hline Sample Formulation & Tensile Strength (Mpa) \\
\hline PPXya 0,1\% & 43,90 \\
\hline PPXyb 0,2\% & 51,74 \\
\hline PPXyc 0,3\% & 51,41 \\
\hline PLA-PCL Murni & 30.41 \\
\hline
\end{tabular}

Based on the tests carried out, it describes the magnitude of the tensile strength value of each sample at different composition variations. Based on the table, it can be seen that the addition of filler material shows a better increase in tensile strength to the polymer when compared to the original polymer without mixing. The tensile strength values of the three samples were in the range of 40 to $50 \mathrm{Mpa}$, while the tensile strength value of pure PLA was only $30 \mathrm{MP}$, so there was an effect of the addition of catechin and chitosan fillers and the addition of ZnO to PLA/PCL. J.bonilla et al in their research adding chitosan to PLA with filler concentration can show a decrease in tensile strength measurement results. However, the addition of chitosan to PPXyb resulted in an increase in the tensile strength value of $51.77 \mathrm{Mpa}$. Based on observations, the PPXyb sample experienced an increase in tensile strength due to the addition of $0.2 \%$ catechin and chitosan filler composition, but when the chitosan composition was added the tensile strength value decreased, this result is in accordance with the observations of J. bonila et al, when the mixer is replaced with bentonite, the value the resulting tensile strength increases. The following is a graph of the tensile test results that have been obtained. Byung Kook Lee et al. (2016), Tyler et al. (2016)

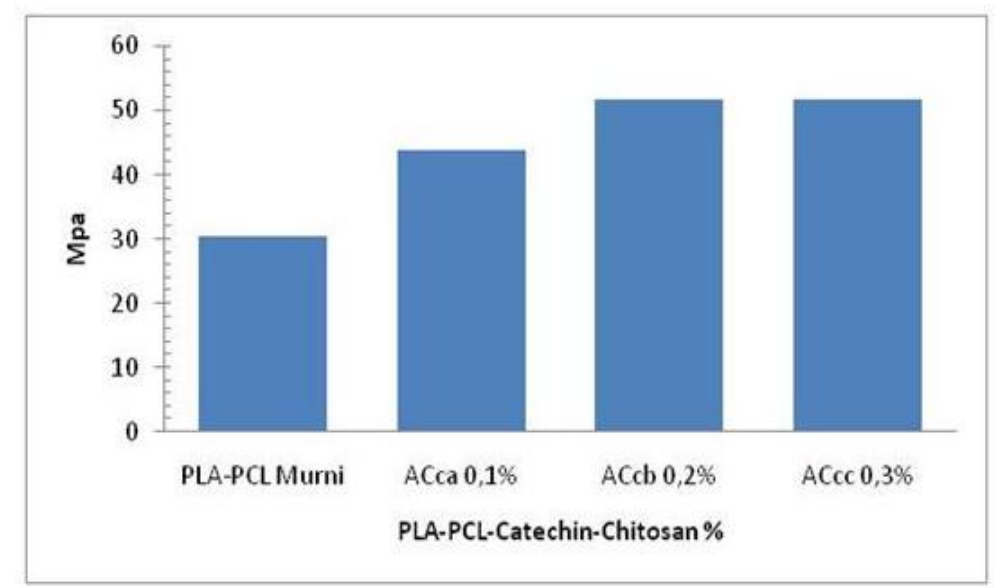

Figure 4 Graph of PLA-PCL-Catechin-Chitosan tensile test (\%)

\section{CONCLUSIONS AND RECOMMENDATIONS}

From the results of the research that has been carried out, it can be concluded that PLA/PCL-Catechin-Chitosan with the addition of $\mathrm{ZnO}$ catalyst in the Thermogravimetric (TGA) test proved that PLA-PCL-Catechin-Chitosan without the addition of $\mathrm{ZnO}$ catalyst burned at $361^{\circ} \mathrm{C}$, this is because the boiling point poly lactic acid (PLA) was at a temperature of 200. However, with the addition of ZnO to PLAPCL-Catechin-Chitosan there was an increase in thermal stability. Thermogravimetric testing (TGA) obtained results for $0.1 \%$ (PPXya) was $361^{\circ} \mathrm{C}$, $0.2 \%$ (PPXyb) was $375^{\circ} \mathrm{C}$ and $0.3 \%$ (PPXyc) was $387^{\circ} \mathrm{C}$. From the results of the 
Scanning Electron Microscopy (SEM) analysis with 200x magnification, it can be seen that the structure of the sample with the addition of a $\mathrm{ZnO}$ catalyst as much as $0.3 \%$ and a processing time of 2 hours shows the form of lumps that are widely spread over the surface and appear smoother. The results of the analysis using Fourier Transform Infrared (FTIR) proved that the PLA-PCL-Catechin-Chitosan produced had $\mathrm{O}-\mathrm{H}, \mathrm{C}-\mathrm{O}$ and $\mathrm{C}=0$ groups with the addition of $0.3 \% \mathrm{ZnO}$ catalyst as the best condition at 2 hours polymerization process. the Fourier Transform Infrared (FTIR) value obtained is to have an $\mathrm{OH}$ group of $3860^{\circ} \mathrm{C}$, a functional group of $\mathrm{CO} 1060^{\circ} \mathrm{C}$ and a functional group of $\mathrm{C}=01753^{\circ} \mathrm{C}$ with the addition of a $\mathrm{ZnO}$ catalyst as much as $0.3 \%$ (PPXyc). And from the tensile strength results, the best tensile test value is found at a $0.3 \% \mathrm{ZnO}$ concentration of $51.74 \mathrm{Mpa}$.

\section{ACKNOWLEDGEMENTS}

The authors express their gratitude and thanks to the Education, Culture, Research and Technology Ministry of the Republic of Indonesia for the financial support through grant Number: 849/E4.1/AK.04.PT/PNL/2021.

\section{REFERENCES}

Aneta K. Urbanek, Aleksandra M. Mirończuk, Alberto García-Martín, Ana Saborido, Isabel de la Mata, Miguel Arroyo. (2020) Biochemical properties and biotechnological applications of microbial enzymes involved in the degradation of polyester-type plastics. Biochimica et Biophysica Acta (BBA) - Proteins and Proteomics. 1868, 140315. Retrieved from https://doi.org/10.1016/j.bbapap.2019.140315

Arfat, Y.A.; Ahmed, J.; Ejaz, M.; Mullah, M. (2018) Polylactide/graphene oxide nanosheets/clove essential oil composite films for potential food packaging applications. Int. J. Biol. Macromol. 107, 194-203. Retrieved from https://doi.org/10.1016/j.ijbiomac.2017.08.156

Betty Tyler, David Gullotti, Antonella Mangraviti, Tadanobu Utsuki, Henry Brem. (2016) Polylactic acid (PLA) controlled delivery carriers for biomedical applications. Advanced Drug Delivery Reviews.107, 163-175. Retrieved from https://doi.org/10.1016/j.addr.2016.06.018

Byung Kook Lee, Yeonhee Yun, Kinam Park. (2016) PLA micro- and nano-particles. Advanced Drug Delivery Reviews. 107, 176-191. Retrieved from https://doi.org/10.1016/j.addr.2016.05.020

Chen, P.; Liang, X.; Xu, Y.; Zhou, Y.; Nie, W. (2018) Enhanced thermal and mechanical properties of PLA/MoS2 nanocomposites synthesized via the in-situ ringopening polymerization. Appl. Surf. Sci. 440, 1143-1149. Retrieved from https://doi.org/10.1016/j.apsusc.2018.01.260

Haghighi, H.; Licciardello, F.; Fava, P.; Siesler, H.W.; Pulvirenti, A. (2020) Recent advances on chitosan-based films for sustainable food packaging applications. Food Packag. Shelf Life. 26, 100551. Retrieved from https://doi.org/10.1016/j.fpsl.2020.100551

Ilknur Yildirim, Christine Weber, Ulrich S. Schubert. (2018) Old meets new: Combination of PLA and RDRP to obtain sophisticated macro molecular architectures. Progress in Polymer Science. 76, 111-150. Retrieved from https://doi.org/10.1016/j.progpolymsci.2017.07.010

Indumathi, M.P.; Rajarajeswari, G.R. (2019) Mahua oil-based polyurethane/chitosan/nano ZnO composite films for biodegradable food 
packaging applications. Int. J. Biol. Macromol. 124, 163-174. Retrieved from https://doi.org/10.1016/j.ijbiomac.2018.11.195

J Jaafar, JP Siregar, C Tezara, MHM Hamdan, T Rihayat. (2019) review of important considerations in the compression molding process of short natural fiber composites. The International Journal of Advanced Manufacturing Technology. 105, 1-13. Retrieved from https://doi.org/10.1007/s00170019-04466-8

Jamshidian, M., Tehrany, EA., Imran, M., Jaquot, M., Desobry, S. (2010) Poly-Lactid Acid Production Application, Nanocomposites And Release Studies. Comprehensive Reviews In Food Science and Food Safety. 9, 560. Retrieved from https://doi.org/10.1111/j.1541-4337.2010.00126.x

Jiang-Ze Wang, Ming-Liang You, Zhen-Qi Ding, Wen-Bin Ye. (2019) A review of emerging bone tissue engineering via PEG conjugated biodegradable amphiphilic copolymers. Materials Science and Engineering: C, 97, 10211035. Retrieved from https://doi.org/10.1016/j.msec.2019.01.057

Juliana Palacio, Natalia A Agudelo, Betty Lucy Lopez. (2018) PEGylation of PLA nanoparticles to improve mucus-penetration and colloidal stability for oral delivery systems. Current Opinion in Chemical Engineering. 11, 14-19. Retrieved from https://doi.org/10.1016/j.coche.2015.11.006

L.K. Kian, N. Saba, M. Jawaid, M.T.H. Sultan. (2019) A review on processing techniques of bast fibers nanocellulose and its polylactic acid (PLA) nanocomposites. International Journal of Biological Macromolecules. 121, 1314-1328. Retrieved from https://doi.org/10.1016/j.ijbiomac.2018.09.040

Ling-Yu Li, Lan-Yue Cui, Rong-Chang Zeng, Shuo-Qi Li, Xiao-Bo Chen, Yufeng Zheng, M. Bobby Kannan. (2018) Advances in functionalized polymer coatings on biodegradable magnesium alloys - A review, Acta Biomaterialia, 79, 23-36. Retrieved from https://doi.org/10.1016/j.actbio.2018.08.030

Lopes, M S. (2014) Synthesis And Charactrization of Poly (Lactid Acid) by Ring Opening Polimerization for Biomedical Application. Chemical Engineering Transsaction. 38, 333.

Mansa, R., Huang, C-Te., Quintel, A., Rocha, F., Detellie, C. (2015) Preparation And Characterization Of Novel Clay/Pla Nanocomposites. Applied Clay Science. 115 , 87-96. Retrieved from https://doi.org/10.1016/j.clay.2015.07.024

Marczak Daria, Lejcuś Krzysztof, Misiewicz Jakub. (2020) Characteristics of biodegradable textiles used in environmental engineering: A comprehensive review. Journal of Cleaner Production. 268, 122129. Retrieved from https://doi.org/10.1016/j.jclepro.2020.122129

Moataz A. Elsawy, Ki-Hyun Kim, Jae-Woo Park, Akash Deep. (2017) Hydrolytic degradation of polylactic acid (PLA) and its composites. Renewable and Sustainable Energy Reviews. 79, 1346-1352. Retrieved from https://doi.org/10.1016/j.rser.2017.05.143

Najafi, N., Heuzey, M.C., Carreau, P.J. (2012) Polylactide (Pla)-Clay Nanocomposites Prepared By Melt Compounding In The Presence Of A Chain Extender. Composites Science and Technology. 72, 608-615. Retrieved from https://doi.org/10.1016/j.compscitech.2012.01.005

Prapruddivongs. C., Sombatsompop, N., Jayaraman, K., Jayaraman, K. (2014) Effect of Organoclay Incorporation on Mechanical, Barrier and Thermal Properties and Anti-Bacterial Performance of Pla and Pla Composites with Triclosan 
and Wood Flour. Polymers and Polymer Composites. 22, 643-652. Retrieved from https://doi.org/10.1177/096739111402200708

Raquez, J.M., Habibi, Y., Murariu, M., Dubois, P. (2013) (PLA)-based Nanocomposites, Progress in Polymer Science. 381, 1504-1542. Retrieved from https://doi.org/10.1016/j.progpolymsci.2013.05.014

Rihayat, T. Suryani. (2010) Synthesis and Properties of Biobased Polyurethane / Montmorillonite Nanocomposites. International Scholarly and Scientific Research \& Innovation. 4 (5), 714-718.

Rihayat, T., Suryani., Teuku, Fauzi., Agusnar, H., Wirjosentono, B., Syafruddin., Helmi., Zulkifli., Alam.P.N., Sami, M.. (2018) Mechanical properties evaluation of single and hybrid composites polyester reinforced bamboo, PALF and coir fiber. Materials Science and Engineering. 334, 1-8. Retrieved from https://doi.org/10.1088/1757-899X/334/1/012081

Safitri, Nelly, Syahputra, R, Putri, K, Rihayat, Teuku, Aidy, Nurhanifa. (2020) Refining Citronella Oil (Cymbopogon Nardus L) by Utilizing Sunlight Using Solar Cells (Photovoltaics). IOP Conference Series: Materials Science and Engineering. 854, 01205. Retrieved from https://doi.org/10.1088/1757899X/854/1/012051

Shady Farah, Daniel G. Anderson, Robert Langer. (2016) Physical and mechanical properties of PLA, and their functions in widespread applications - A comprehensive review. Advanced Drug Delivery Reviews. 107, 367-392. Retrieved from https://doi.org/10.1016/j.addr.2016.06.012

Sun, M.L., Pei, W.L. (2017) Effect of Thermoplastic Polyurethane-Modified Silica on Melt-Blended Poly (Lactic Acid) (PLA) Nanocomposites. Polymers and Polymer Composites. 25, 583-592. Retrieved from https://doi.org/10.1177/096739111702500803

Suryani, Fitria, Rihayat, Teuku, Aidy, Nurhanifa, Hasnah, T. (2020) Chitosan Modified Bio-Fibre Based Board as Antimicrobial and Anti-Crack Board. IOP Conference Series: Materials Science and Engineering. 854, 012050. Retrieved from https://doi.org/10.1088/1757-899X/854/1/012050

Suryani., Harry, A., Basuki, W., Teuku, R., Nurhanifa. (2017) Improving the quality of biopolymer (poly lactic acid) with the addition of bentonite as filler. Materials Science and Engineering. 222, 1-7. Retrieved from https://doi.org/10.1088/1757-899X/222/1/012008

Suyono, Yoyon. (2012) Studi Awal Pembuatan Nanokomposit dengan Filler Organoclay Untuk Kemasan. Biopropal Industri. 3, 63-69. Retrieved from http://ejournal.kemenperin.go.id/files010483/journals/12/articles/740/ public/740-1934-2-PB.pdf

T Rihayat, S Salim, A Arlina, Z Fona, R Jalal, PN Alam, M Sami, J Syarif, N Juhan. (2018) Determination of CEC value (cation exchange capacity) of bentonites from North Aceh and Bener Meriah, Aceh Province, Indonesia using three methods. IOP Conference Series: Materials Science and Engineering. 334, 17. Retrieved from https://doi.org/10.1088/1757-899X/334/1/012054

Teuku Rihayat, Suryani, Satriananda, Ridwan, Nurhanifa, Alfian Putra, Nia Audina, Muhammad Yunus, Sariadi, Safari, Ramzi Jalal, Nani Siska Putri Khan, Saifuddin. (2018). Influence of coating polyurethane with mixture of bentonite and chitosan nanocomposites. AIP Conference Proceedings, Vol. 2049, 1-6. Retrieved from https://doi.org/10.1063/1.5082425

Tosati, J. V; de Oliveira, E.F.; Oliveira, J.V.; Nitin, N.; Monteiro, A.R. (2018) Lightactivated antimicrobial activity of turmeric residue edible coatings against 
cross-contamination of Listeria innocua on sausages. Food Control. 84, 177185. Retrieved from https://doi.org/10.1016/j.foodcont.2017.07.026

Zejun Xu, Danyang Wang, Yanqin Cheng, Mingshi Yang, Lin-Ping Wu. (2018) Polyester based nanovehicles for siRNA delivery. Materials Science and Engineering: C. 92, 1006-1015. Retrieved from https://doi.org/10.1016/j.msec.2018.05.031

Zibiao Li, Beng Hoon Tan, Tingting Lin, Chaobin He. (2016) Recent advances in stereocomplexation of enantiomeric PLA-based copolymers and applications. Progress in Polymer Science. 62, 22-72. Retrieved from https://doi.org/10.1016/j.progpolymsci.2016.05.003

Zulkifli , Teuku Rihayat, Suryani , Facraniah , Ummi Habibah, Nia Audina, Teuku Fauzi, Nurhanifa, Zaimahwati, Rosalina. (2018) Purification process of jelantah oil using active chorcoal kepok's banana. AIP Conference Proceedings. 1, 1-6.]. Retrieved from https://doi.org/10.1063/1.5082427 